\title{
COMPARATIVE ANALYSIS OF REVERSE E-LOGISTICS' SOLUTION IN ASIA AND EUROPE
}

\author{
Mohamad AL MAJZOUB ${ }^{1}$, Vida DAVIDAVIČIENĖ ${ }^{2 *}$ \\ ${ }^{1,2}$ Department of Business Technologies and Entrepreneurship, Faculty of Business Management, \\ Vilnius Gediminas Technical University, Sauletekio al. 11, LT-10223, Vilnius, Lithuania \\ *E-mail: vida.davidaviciene@vgtu.lt
}

\begin{abstract}
Purpose - to make comparative analysis of the most successful reverse e-logistics' solution in Asia and Europe to identify models and methods for solving efficiency and sustainability issues in these areas.

Research methodology - the research methodology implemented is composed of literature review, synthesis, and comparative analysis.

Findings - certain solutions implemented such as omni-channels, and Multi-criteria decision making (MCDM) in Asia, and selecting the best third-party reverse logistics providers (3PRLPs), and green suppliers in Europe were able to increase the efficiency of reverse e-logistics' performance.

Research limitations - the lack of enough researches done in the field of RL in the Middle East created obstacles in double checking the work presented in this paper because more resources are needed to confirm significantly the results. As for future recommendations, further researches should be conducted in the Middle East.

Practical implications - the results found can be implemented in those firms who are still suffering inefficiencies and high costs in their reverse e-logistics' activities.

Originality/Value - this research made a comparison study between solutions implemented in Europe and Asia in headto-head comparison in such a way it gave an originalitity of these values since no previous researches and studies were conducted in that comparative way before.
\end{abstract}

Keywords: reverse logistics, e-logistics, e-commerce, reverse e-logistics, supply chain.

JEL Classification: M16, M160.

Conference topic: Digitalization of Business Processes: Trends, Challenges, and Solutions.

\section{Introduction}

Reverse Logistics (RL) is the summation of processes of gathering, examination, categorization, fixing, refurbishing, remanufacturing, recycling as well as clearance, of the products to take them back from their current source of consumption to their original source of manufacturing or delivering (Agarwal, Govindan, Darbari, \& Jha, 2016). Reverse logistics is initiated from the consumer into the raw material supplier, and it focuses on well-planning, operating, and handling the efficient flow of different materials, information, and money, recovering at the same time the residual value from end-of-life and end-of-use products (Yu \& Solvang, 2016). There exist four main categories of reverse logistics methods. They are the direct reuse, remanufacturing, recycle, and landfill (Chinda, 2017). Reverse e-logistics' costs from returned products registered for 2015 an amount of 130.6 billion U.S. dollars in Asia-pacific, and 223.6 billion U.S. dollars in the EMEA region, and these costs are expected to continue increasing. Moreover, the costs of returned goods alone worldwide are more than $\$ 260$ billion a year and an average profit loss of $10 \%$. Actually, $87 \%$ of firms stated that the effective management of the RL was tremendously important to their operational and financial performance (Shaik \& Abdul-Kader, 2018)). Return's rate has been enlarged by $57 \%$ for retailers and $43 \%$ for manufacturers respectively during the last three to five years. Several firms suffer significantly from ineffective management of returned goods. The costs of returned goods alone worldwide are more than $\$ 260$ billion a year and an average profit loss of 10\% (Han \& Trimi, 2018). Approximately $8 \%$ of retailers' total sales are attributed to reverse logistics. Actually, about $10 \%$ of online transactions comprise what is called "return sales", annulment, and repayment demands (Tavengerwei, 2018). Thus, this necessitates the fast, efficient, and effective solutions to be applied. Because of its operations' ambiguity and complexity, the performance measurement of RL is rarely studied (Brüning Larsen, Masi, \& Cordes 
Feiber, 2017; Shaik \& Abdul-Kader, 2018). RL is considered as a strategic tool for manufacturing firms since it permits them to gain a competitive advantage by granting a reputable image, customer loyalty, as well as an improvement in their relative market presence. Moreover, RL leads to a reduction in the operational costs by make the most of the recovery from used-goods (Agarwal et al., 2016). Reverse Logistics decreases waste of resources and thus increases efficiency. This is done by improving the quality of secondary materials and enhancing the utilization of natural resources (Chileshe, Rameezdeen, Hosseini, Martek, Li, \& Panjehbashi-Aghdam, 2018). Furthermore, reverse logistics initiatives with social commerce including e-commerce and social networks. This will give opportunities for enterprises to have other sources to increase their sales, and to play a role in their corporate social responsibility via social, green, and environmental activities, as well (Han \& Trimi, 2018). The reduction of costs that RL supports is due to the saving of raw materials and spare parts when RL is performed efficiently. Moreover, RL yield revenues by reselling materials and products after being scrapped. Indeed, the effective process management of RL in its product returning allows the enhancement of productivity, thus gaining a competitive advantage by that, in addition to the costs' reduction. An important result of effective RL will be the customer satisfaction that can be achieved that in turn will yield customer loyalty and thus retention. Customer satisfaction is attained when resources are used to develop process capabilities and service quality (Panigrahi, Kar, Fen, Hoe, \& Wong, 2018). Actually, a substantial profit accompanying with RL is also related to the recovery value of the goods being returned. An important advantage of RL is that deals with both economic and environmental aspects, whereas in the normal forward supply chain, economic aspects are only considered (Tosarkani \& Amin, 2018). Inappropriately, the literature regarding preceding works as well as the results in RL progress is rare (Euchi, Bouzidi, \& Bouzid, 2018). Slight attention has been focused on the factors affecting the effective implementation of RL practices in developing countries (Prakash \& Barua, 2015.). Returns management is probably the most abandoned part in thee-logistics' practices (Panigrahi et al., 2018). Numerous firms have implemented reverse logistics RL in their strategies and policies to ensure continuous improvement and development by concentrating on decreasing of resources' wasting and by providing value from returned used-products (Sirisawat \& Kiatcharoenpol, 2018). Designing a well-planned RL system will lead to several benefits such as economic and environmental ones. Nevertheless, an inadequately designed reverse logistics system will decrease firms' profitability and at the same time causing significant environmental and social problems. Hence, developing an innovative decisionmaking instrument for RL system is of significant importance (Yu \& Solvang, 2017). RL reflects a very effective solution for value recovery from end-of-life and end-of-use products (Yu \& Solvang, 2016). Despite the fact that there are several factors that can impact RL, yet but what contributes the most to impact the effective implementation of RL is the understanding of the opportunities granted by reverse logistics supply chain itself in development of customers' loyalty as well as satisfaction and loyalty (Prakash \& Barua, 2015). Effective RL performance will yield efficient resource using, in addition to pollution prevention by decreasing an environmental load of end-of-life (EOL) at its foundation (Prakash \& Barua, 2015). There are several factors that hinder the effective implementation and integration of RL with the current forward supply chain system. Some of the most important factors include lack of knowledge and lack of government support, financial limitations, and market constraints. In addition to that, there exists a case of "lack of awareness" among the consumers as well as manufacturers regarding the possible benefits of engaging in reverse logistics (Agarwal et al., 2016). Other numerous barriers that make RL implementation difficult are Management barriers, bad infrastructure, legal, economical organizational, and market-related. The problem is that the effect of these barriers cannot be overcome at the same time (Prakash \& Barua, 2015). A big concern in an RL system is handling of the returned products (either because they are defective or obsolete) through an efficient reverse logistics system, in a way that these returned products arrive at their final destinations with the lowest costs possible (Eskandarpour, Masehian, Soltani, \& Khosrojerdi, 2014). Furthermore, in the majority of models in RL system, the seller is the one who is held responsible for the costs incurred because of returned goods, and this might be strongly hectic for companies and especially MSMEs. In certain situations, there is a kind of transparency in customs procedures that ease the processes, yet still, not all are satisfactory (Tavengerwei, 2018). However, some gaps exist in measuring the performance of a reverse logistics firm. In order to fill those gaps by identifying weak areas, therefore adequate programs should be developed.

The purpose of this study is to find solutions to increase the efficiency of reverse logistics implementation and to solve effectively the resource shortage that most firms face. Thus the objective is two-fold: (1) to identify the factors that influence the efficiency reverse logistics and to know their impact on RL, and (2) to make a comparative analysis of RL solution that have been already been implemented in both Asia and Europe to increase efficiency of RL's performance and to promote development sustainability. Hence, the following research questions could be posed to understand more the underlying causes. Research Question 1: What are the factors that affect the perceived efficiency of RL and to what extent do these factors affect RL's performance. For Research Question 2: What are the methods and solutions implemented in Europe and Asia and how would a comparison analysis between the applied solutions in these areas help in increasing the efficiency of RL's performance?

The methods used in this study are, literature review, synthesis, and comparative analysis. In the next sections in this article we will first discuss the main essence of reverse logistics, then next the factors that have a direct influence on reverse logistics' performance, then the basic solutions implemented effectively in Europe and Asia and a comparison study will be discussed. 


\section{The main essence of different reverse logistics' perspectives}

RL is seen from different perspectives according to different authors and this is manifested in the different definitions that exist for RL. For instance, RL is known as the process of planning, employing, and adjusting the efficient, costeffective movement of raw materials, in-process inventory, finished goods and linked information from the consumer to the origin site in an attempt to recollect products or to dispose of them (Sirisawat \& Kiatcharoenpol, 2018). Moreover, Reverse logistics is considered to be not only these steps mentioned above but it is perceived as the whole procedure for effectively handling the material, info and money stream so as to renew value from the end-of-use (EOU) and end-of-life (EOL) products via repairing, reutilizing, remanufacturing, recycling and reinstatement to the marketplace. Furthermore, RL comprises the suitable handling of the non-reusable and nonrecyclable components (Yu \& Solvang, 2017). Reverse logistics contain activities linked to product recovery containing returned product acquisition, product disassembly, remanufacturing, and remarketing (Tosarkani \& Amin, 2018). The main basic definitions of reverse logistics are summarized in Table 1.

Table 1. Different definitions of reverse logistics compiled by author (source: composed by authors)

\begin{tabular}{|c|c|}
\hline Definition of Reverse Logistics & Author \\
\hline $\begin{array}{l}\text { Summation of processes of gathering, examination, categorization, fixing, refurbishing, remanufac- } \\
\text { turing, recycling as well as clearance, of the products to take them back from their current source of } \\
\text { consumption to their original source of manufacturing or delivering. }\end{array}$ & Agarwal et al., 2016 \\
\hline $\begin{array}{l}\text { The process of planning, employing and adjusting the efficient, cost-effective movement of raw ma- } \\
\text { terials, in-process inventory, finished goods and linked information from the consumer to the origin } \\
\text { site in an attempt to recollect products or to dispose of them. }\end{array}$ & $\begin{array}{l}\text { Sirisawat and } \\
\text { Kiatcharoenpol, } 2018\end{array}$ \\
\hline $\begin{array}{l}\text { Reverse logistics is the whole procedure for effectively handling the material, info and money } \\
\text { stream so as to renew value from the end-of-use (EOU) and end-of-life (EOL) products via repair- } \\
\text { ing, reutilizing, remanufacturing, recycling and reinstatement to the marketplace. Furthermore, RL } \\
\text { comprises the suitable handling of the non-reusable and non-recyclable components. }\end{array}$ & Yu and Solvang, 2017 \\
\hline $\begin{array}{l}\text { RL refers to operations and procedures for returning post-sale and post-consumption goods back } \\
\text { into the production cycle, by way of reversing distribution channels. }\end{array}$ & Chileshe et al., 2018 \\
\hline $\begin{array}{l}\text { The process of planning, implementing and controlling the efficient, cost-effective flow of raw ma- } \\
\text { terials, in-process inventory, finished goods and related information from the point of consumption } \\
\text { to the point of origin for the purpose of recapturing value or proper disposal. }\end{array}$ & Han and Trimi, 2018 \\
\hline $\begin{array}{l}\text { Rogers and Tibben-Lembke (1999) define RL as the process of planning, implementing, and con- } \\
\text { trolling the efficient, cost-effective flow of raw materials, in-process inventory, finished goods, and } \\
\text { related information from the point of consumption to the point of origin for the purpose of recaptur- } \\
\text { ing or creating value or proper disposal. }\end{array}$ & $\begin{array}{l}\text { Shaik and Abdul- } \\
\text { Kader, } 2018\end{array}$ \\
\hline $\begin{array}{l}\text { In reverse logistics systems, a product coming from the reuse of materials embedded into wastes re- } \\
\text { turns to the manufacturer after use and can be repaired or remanufactured to be delivered again to } \\
\text { make new products with secondary raw materials to the end consumers. The key processes are iden- } \\
\text { tified as product acquisition, collection, inspection and sorting, and disposition. }\end{array}$ & Sun, 2017 \\
\hline $\begin{array}{l}\text { RL includes all activities associated with product recovery such as repairing, recycling, remanufac- } \\
\text { turing, and disposing of. Several partners are required to collaborate efficiently on account of ob- } \\
\text { taining optimal outcomes. Prakash and Barua (2016) categorized RL into the main activities of } \\
\text { waste logistics and recovery logistic. }\end{array}$ & $\begin{array}{l}\text { Tosarkani and Amin, } \\
2018\end{array}$ \\
\hline $\begin{array}{l}\text { Reverse logistics as "returning defective, damaged or unused products to the retail outlets". It en- } \\
\text { compasses all the processes described in the supply chain but in a reverse manner from customer to } \\
\text { retailer. Reverse logistics in the retail industry include recalled products, end of life products, sea- } \\
\text { son returns, and disposal. }\end{array}$ & Panigrahi et al., 2018 \\
\hline The goal of reverse logistics is to focus on the reverse flow of materials by maximizing their value. & Han and Trimi, 2018 \\
\hline $\begin{array}{l}\text { Reverse logistics contain activities linked to product recovery containing returned product acquisi- } \\
\text { tion, product disassembly, remanufacturing, and remarketing. }\end{array}$ & $\begin{array}{l}\text { Tosarkani and Amin, } \\
2018\end{array}$ \\
\hline
\end{tabular}

Briefly, RL, as a matter of fact, includes products manifested into one of two categories. The first one is concerned with goods which are returned by consumers to their corresponding point-of-origin either due to the fact that these goods didn't succeed to function as intended and designed, or either because there is a lack of customer satisfaction, regardless of what the reason really is. In such conditions, the goods returned are vented to a secondary market in either a repaired-form or refurbished item. Concerning the second category, it has to do with everything related to products gathered from their perspective consumers in order to process of "recovery" after they attained the end of their useful lives efficiently (Batarfi, Jaber, \& Aljazzar, 2017). 


\section{Factors affecting reverse logistics}

There are several authors that discussed the factors that affect reverse logistics (Lau \& Wang, 2009; Lian, 207; Meixell \& Luoma, 2015). According to Prakash and Barua (2015), Sirisawat and Kiatcharoenpol (2018), the factors affecting the efficient implementation of reverse logistics in developing countries are managerial, organizational, economic, legal, technological, infrastructural, and market-related factors. According to Bogataj and Grubbström (2013), transportation still is playing a negative role in developing countries. This is happening due to the high costs of transportation in reverse activities especially to far dislocations because of the bad transportation system of merchandise and logistics. From another perspective, Government policies and Organizational structure are the greatest guiding elements that have the utmost effect in driving others factors and systems the base of explanatory structure exemplary (Euchi et al., 2018). Distance factors motivate firms to apply reverse logistics into their operational business activities. Such factors are categorized into three key factors, the legislative, profit-oriented driver, and corporate citizenship factors, respectively (Chinda, 2017). From another perspective, choosing the best reverse logistics' partners directly affects reverse logistics activities and needs a multi-criteria decision making (MCDM) approach to solve. Thus, applying this solution will help reach the ideal third-party reverse logistics provider (Tosarkani \& Amin, 2018). Nevertheless, there are selective factors that directly influence the effective growth and improvement of reverse logistics. These are: lack of natural resources, environmental laws, the understanding of backward flow value, e-commerce enhancement, decent reputation necessities, consumer satisfaction, and the quality of information systems including social commerce platform such as social networking services/sites, management such as customer relationship and quality control, technology such as social media, and social activities such as forums and communities (Han \& Trimi, 2018). In another study done by Govindan and Bouzon (2018), factors affecting RL are categorized as either internal or external. External ones comprise barriers from outside of the organizations that interrupt the proper implementation of $\mathrm{RL}$, whereas the internal ones comprise opportunities such as internal technology and infrastructure, governance and supply chain activities, economic, knowledge, policy, market and competitors, and management associated subjects. Factors affecting reverse logistics can also be categorized in terms of product, inventory, warranty, and core returns in addition to reusable containers, damaged goods (which represent highest one of $20 \%$ of returns), seasonal items, hazardous materials, and stock adjustments (Panigrahi et al., 2018). Finally, it is worth mentioning that customers return products due to commercial return, end of use return, end of life return, repair and warranty return over the product life cycle (Tosarkani \& Amin, 2018). In another study done, the critical factors that affect reverse logistics are split

Table 2. Factors affecting reverse logistics compiled by author (source: composed by authors)

\begin{tabular}{|l|l|}
\hline \multicolumn{1}{|c|}{ Main Factors that affect RL's performance } & \multicolumn{1}{|c|}{ Authors } \\
\hline $\begin{array}{l}\text { Managerial, organizational, economic, legal, technological, infrastructural, and market-related fac- } \\
\text { tors. }\end{array}$ & $\begin{array}{l}\text { Prakash and Barua, } \\
\text { 2015; Sirisawat and } \\
\text { Kiatcharoenpol, 2018 }\end{array}$ \\
\hline Transportation & $\begin{array}{l}\text { Bogataj and } \\
\text { Grubbström, 2013 }\end{array}$ \\
\hline Government policies and Organizational structure & Euchi et al., 2018 \\
\hline $\begin{array}{l}\text { Three main categories, including 1) legislative driver, 2) profit-oriented driver, and 3) corporate citi- } \\
\text { zenship driver }\end{array}$ & Chinda, 2017 \\
\hline $\begin{array}{l}\text { Selection of partners/ third-party reverse logistics provider } \\
\text { Natural resources, environmental law, the realization of backward flow value, e-business develop- } \\
\text { ment, good reputation requirement, customer satisfaction, quality of information systems including } \\
\text { social commerce platform such as social networking services/sites. }\end{array}$ & $\begin{array}{l}\text { Tosarkani and Amin, } \\
2018\end{array}$ \\
\hline $\begin{array}{l}\text { External factors such as the environment, and internal factors such as technology infrastructure, } \\
\text { governance, economic, knowledge, and competitors. }\end{array}$ & $\begin{array}{l}\text { Govindan and Bou- } \\
\text { zon, 2018 }\end{array}$ \\
\hline $\begin{array}{l}\text { Product recalls (goods that manufacturers recall), inventory returns (to minimize inventory in the } \\
\text { retail outlet), warranty returns (goods required by retailers), core returns (goods that can be reused), } \\
\text { reusable containers (returning the shipment to the manufacturers), damaged goods (goods damaged } \\
\text { on site), seasonal items (after season return), hazardous materials (items that are considered as haz- } \\
\text { ardous to be return) and stock adjustments (transfer of stocks to correct a situation). }\end{array}$ & Panigrahi et al., 2018 \\
\hline $\begin{array}{l}\text { Commercial return, end of use return, end of life return, repair and warranty return over the product } \\
\text { life cycle. }\end{array}$ & $\begin{array}{l}\text { Tosarkani and Amin, } \\
2018\end{array}$ \\
\hline $\begin{array}{l}\text { the finance and economic factors that lead to high cost in reverse logistics, second is the lack of } \\
\text { knowledge and experience, third is lack of government policies (law and regulation), fourth is in the } \\
\text { management and culture (management), fifth is lack of human resources, infrastructure and technol- } \\
\text { ogy, lack of environmental awareness, lack of community pressure, and company policies }\end{array}$ & Waqas et al., 2018 \\
\hline
\end{tabular}


into the following several categories: the finance and economic factors that lead to high cost in reverse logistics, second is the lack of knowledge and experience, third is lack of government policies (law and regulation), fourth is in the management and culture (management), fifth is lack of human resources, infrastructure and technology, lack of environmental awareness, lack of community pressure, and company policies (Waqas, Dong, Ahmad, Zhu, \& Nadeem, 2018). Table 2 below summarizes the main factors affecting reverse logistics.

As noted from the above table, several differences exist between the important factors that should be considered and included in reverse logistics operations. However, despite these distinctions, there still exist several common points as well, that is worth building on to create an integrative perspective of a solution model to increase the efficiency of reverse logistics' performance.

\section{Solutions implemented for increasing efficiency of reverse logistics performance}

The following section deals with solutions implemented in both Europe and Asia. Firms deal with RL and product returns in a completely different manner. Every firm chooses the method according to its needs, capabilities, and the way it affects its revenues (Panigrahi et al., 2018). Certain solutions implemented were able to increase the efficiency of reverse e-logistics, others didn't make that huge effect. Only the most important solutions will be discussed in this article.

\subsection{Solutions implemented for increasing efficiency of reverse Logistics performance in Europe}

The complexity of reverse logistics always initiate solutions to be original and creative, and the methods applied to improve reverse logistics' performance have to be efficient and cost-effective (Shaik \& Abdul-Kader, 2018). For instance, the application of omin-channels in retail industry proved to be effective. However, if proper transportation is missing and regulations are tight, this will not yield the intended results (Panigrahi et al., 2018). Another solution is the application of a social commerce platform, a novel business method of e-commerce that takes advantage of social media and Web 2.0 technologies in order to back social-related exchange activities. This platform allows consumers to interact and stay connected with the firms thus integrating e-business, customer relationship management, technology support, and information systems (Han \& Trimi, 2018). Choosing best third-party reverse logistics is an important factor that affects reverse logistics performance. This can be solved by applying Fuzzy Topsys through three basic main steps. The first is manifested by choosing election of the best third-party reverse logistics providers (3PRLPs) or green suppliers. Second is the location decision problem. The third one is Reverse logistics process (Han \& Trimi, 2018). RL is a complex process by itself, thus sustaining its efficiency is not that easy. Sustainability is done in one of two ways. The first is to sustain implementation and application or reverse logistics, whereas the second one is to emphasize raising awareness in using resources more efficiently (Bal \& Satoglu, 2018). Actually, achieving a sustainable supply chain is done through the duty that each fragment has in terms of being environmentally friendly in diverse activities such as goods design, production, utilization, recycling, as well as transportation (Linton, Klassen, \& Jayaraman, 2007). The solution applied to analyze and improve sustainability is the triple bottom line (TBL) approach, which states that for reverse logistics to be sustainable, the economic, environmental and social requirements got be attained at the lowest possible cost (Bal \& Satoglu, 2018). Another advantage of this approach is that it does not only reduce cost but reduces greenhouse gas emissions as well thus gaining an additional competitive advantage and being socially responsible firm. Operational activities by themselves lead to high costs, if not managed properly, due to high emissions of carbon dioxide (Tseng \& Hung, 2014). Challenges of reverse logistics are plenty, but lack of effective systems such as the performance management (PM) system, would render results catastrophic. PM will affect reverse logistic's efficiency when it allocates resources, responsibilities and decision making, setting the objectives of performance, and providing the result by evaluating the targets' attainment. However, firms should be aware not to fall in the trap of studying the factors that affect RL only but should also be aware of the degree of such effect and their interdependency. Thus, it is important for the PM to be linked with multi-criteria approaches especially balanced scorecard and analytic network process (ANP) based approach (Shaik \& Abdul-Kader, 2018). Table 3 documents the most important and effective solutions implemented in Aisa.

Table 3. Reverse Logistics solution implemented in Asia (source: composed by authors)

\begin{tabular}{|l|l|l|c|}
\hline \multicolumn{1}{|c|}{ Method } & \multicolumn{1}{|c|}{ Description } & \multicolumn{1}{c|}{ Author } & \multicolumn{1}{c|}{ Country } \\
\hline $\begin{array}{l}\text { Application of } \\
\text { Omni-channels }\end{array}$ & $\begin{array}{l}\text { Omni-channel involves the integration of process, information flow, } \\
\text { inventory and measurement systems, which are taking care sepa- } \\
\text { rately by individual departments. It involves 4 stages: the first stage } \\
\text { is Inspection and Collection, second is Sorting and Testing, third is } \\
\text { Processing, and the final stage is storage. } \\
\text { Bad implementation of Omni-channels and tighter regulation make } \\
\text { reverse logistics more complex. }\end{array}$ & $\begin{array}{l}\text { Ang and Tan, } \\
2018 \\
\text { et al., 2018 }\end{array}$ & Malaysia \\
\hline
\end{tabular}


End of Table 3

\begin{tabular}{|c|c|c|c|}
\hline Method & Description & Author & Country \\
\hline $\begin{array}{l}\text { fuzzy analytical hierarchy } \\
\text { process (Fuzzy AHP) } \\
\text { Fuzzy TOPSIS }\end{array}$ & $\begin{array}{l}\text { First, identification of RL barriers should be included with proposed } \\
\text { alternative solutions from experts in the field and industry, in addi- } \\
\text { tion to the market research. Second, Fuzzy AHP will be utilized to } \\
\text { get the weight of criteria and sub-criteria of barriers and prioritize } \\
\text { barriers. The third phase applied fuzzy TOPSIS to prioritize and } \\
\text { rank the solutions of RL practice. }\end{array}$ & $\begin{array}{l}\text { Sirisawat and } \\
\text { Kiatcharoen- } \\
\text { pol, } 2018\end{array}$ & Thailand \\
\hline $\begin{array}{l}\text { Decision-Making Trial } \\
\text { and Evaluation Labora- } \\
\text { tory (DEMATEL) } \\
\text { approach }\end{array}$ & $\begin{array}{l}\text { DEMATEL methodology is utilized for the purpose of understand- } \\
\text { ing the mutual relationships between the strategies to extract the } \\
\text { most imperative ones. The DEMATEL approach derives the priori- } \\
\text { ties for the strategies for achieving a feasible partnership among the } \\
\text { stakeholders so that the desired RL network represents the voice and } \\
\text { opinion of every SC member involved. The result of DEMATEL } \\
\text { methodology is a visual representation in the form of an impact-re- } \\
\text { lations map (IRM) which can provide more clarity of the existing } \\
\text { interdependence between various criteria to the DMs. There are } \\
\text { main } 4 \text { steps of DEMATEL. Step 1: Construct the Direct relation } \\
\text { matrix. Step 2: Obtain the Normalized direct relation matrix. Step 3: } \\
\text { Calculate the Total relation matrix T. Step 4: Construct the IRM di- } \\
\text { agram. }\end{array}$ & $\begin{array}{l}\text { Agarwal } \\
\text { et al., } 2016\end{array}$ & India \\
\hline $\begin{array}{l}\text { The augmented dickey } \\
\text { fuller (ADF) test, Johan- } \\
\text { sen cointegration test, and } \\
\text { impulse response. }\end{array}$ & $\begin{array}{l}\text { These methods are utilized to interpret the relationship between re- } \\
\text { verse logistics carbon footprint and the influencing factors ADF is a } \\
\text { method for the root of unity test, is a common choice for testing sta- } \\
\text { tionery of the series. Johansen cointegration test is used to observe } \\
\text { whether future development has an integration impact on the en- } \\
\text { tirety. It is useful due to its ability to determine whether a long-term } \\
\text { stable equilibrium exists between variables. The impulse response } \\
\text { function can capture the dynamic changes of variables. }\end{array}$ & Sun, 2017 & China \\
\hline $\begin{array}{l}\text { Multi-criteria decision } \\
\text { makings (MCDM) such } \\
\text { as the analytic hierarchy } \\
\text { process (AHP) and ana- } \\
\text { lytic network process } \\
\text { (ANP) }\end{array}$ & $\begin{array}{l}\text { The roles of MCDM models are significant in industries and busi- } \\
\text { nesses. Some researchers have considered environmental factors in } \\
\text { MCDM techniques examined green supply chain management } \\
\text { (GSCM) to offer an environmental framework for supplier selection } \\
\text { in the automotive industry. DEMATEL, ANP, and TOPSIS meth- } \\
\text { ods were integrated with fuzzy sets theory to assist in the decision- } \\
\text { making process. }\end{array}$ & $\begin{array}{l}\text { Tosarkani and } \\
\text { Amin, } 2018\end{array}$ & Thailand \\
\hline $\begin{array}{l}\text { Analytic Hierarchy Pro- } \\
\text { cess (AHP) and Entropy } \\
\text { Weight (EW) method. }\end{array}$ & $\begin{array}{l}\text { Integration of AHP and EW for deriving criteria weights. The aim } \\
\text { of this hybrid method is to investigate the major relationship be- } \\
\text { tween criteria and it has } 4 \text { steps. Step 1: Standardization of criteria } \\
\text { data Step 2: Normalization of grey decision-making matrix. Step 3: } \\
\text { Determination of comprehensive weights. Step 4: Determination of } \\
\text { grey border approximation area matrix. }\end{array}$ & $\begin{array}{l}\text { Wang et al., } \\
2019\end{array}$ & China \\
\hline $\begin{array}{l}\text { Hybrid-information } \\
\text { multi-criteria decision } \\
\text { making (HI-MCDM) and } \\
\text { CPT }\end{array}$ & $\begin{array}{l}\text { It solves the 3PRLP selection problem involving the psychological } \\
\text { behavior of a division team, where the evaluation criteria are de- } \\
\text { scribed as real numbers, interval numbers, and linguistic terms. } \\
\text { First, the goals of the decision team and criteria values in three for- } \\
\text { mats are normalized to deal with the incommensurability among the } \\
\text { different forms of criteria values. Given that the goals of the deci- } \\
\text { sion team inherit the CPT property, setting goals as RP is effective } \\
\text { and reasonable. Furthermore, again and loss matrix is built by meas- } \\
\text { uring the distance between the criteria value and relative RP utiliz- } \\
\text { ing the Euclidean distance function. Moreover, the prospect value of } \\
\text { each criterion can be calculated with the value function of CPT } \\
\text { based on the decision team's risk preference toward gain and loss } \\
\text { scenarios. Thus, the overall prospect value of each alternative is as- } \\
\text { sessed by aggregating the prospect values and weights of the criteria } \\
\text { using a simple additive weighting (SAW) approach. Finally, a rank- } \\
\text { ing order of all 3PRLPs is determined according to the obtained } \\
\text { overall prospect values. }\end{array}$ & $\begin{array}{l}\text { Li, Ying, } \\
\text { Chin, Yang, } \\
\text { and } \mathrm{Xu}, 2018\end{array}$ & China \\
\hline
\end{tabular}

What's quite interesting about the findings of these studies implemented in Europe, is that all of these methods proved to be extremely effective in increasing the efficiency of reverse logistics' performance in contrast to many several other studies performed in the same field. 


\subsection{Solutions implemented for increasing efficiency of reverse logistics performance in Asia}

Diverse studies aimed to improve the efficiency of reverse logistics in Asia. For instance, configuring an electronic reverse logistics network and third-party selection has proven to be effective when it comes to reverse logistics as well. A proposed solution states that one of the best methods for a better RL is to apply fuzzy analytic network process (FANP) to change the environmental qualitative factors, that are causing huge costs on the firms, to quantitative. It is made up of 3 steps, the 1st step is to prioritize 3rd parties based on their green performance. The second step is to configure an electronic RL network and solve the mathematical equation. Finally, the third step is to compute nondominated solutions of the multi-objective optimization model to (Tosarkani et al., 2018). Another solution proposed is using Omni-channels that includes incorporation of procedure, the flow of material and information flow, inventory and measurement systems, by distinct departments. Omni-channels proved to be effective since today the customers' trend is switching towards electronic purchases because almost everybody now has smartphones and can access it easily. Another advantage is that it allows retailers to centralize their reverse logistics operations, thus benefiting from economies of scale and lowering their costs (Ang \& Tan, 2018). Reverse logistics system is a crucial system to deliver efficient resource consumption and decreasing waste from the end of life (EOL) goods, especially in the electronics industry. This is achieved by applying the fuzzy analytical hierarchy process (Fuzzy AHP) and fuzzy technique for order performance by similarity to ideal solution (Fuzzy TOPSIS) whereby the fuzzy AHP approach is implemented to acquire the weights of each factor affecting reverse logistics' performance by utilizing pairwise comparison, and fuzzy TOPSIS is implemented to get the final ranking results of the solutions to increase the efficiency of reverse logistics (Sirisawat et al., 2018). The role of the channel partners is very crucial for reverse logistics but is often overlooked. Thus to solve this problem, a collaborative framework that comprises recognizing the convenient solutions for the application of RL and choosing RL partners is required. This solution is the Decision Making Trial and Evaluation Laboratory (DEMATEL) approach, which is an approach to comprehend the mutual relationships among the solutions and implement the most effective ones by making a linear programming problem for the RL channels created under a collaborative framework (Agarwal et al., 2016). Reverse logistics has a significant role in achieving and maintaining sustainable development of competitive advantage especially in enhancing low carbon competitiveness and lower resources usage. This is accomplished through implementation of the quantitative research methodology using ADF test, Johansen cointegration test, and impulse response to analyze the connection between reverse logistics carbon footprint and reverse logistics. Thus maintaining an energy-efficient, and the good remanufacturing rate is more adept of constraining reverse logistics carbon footprint high costs (Sun, 2017). An important aspect of reverse logistics is in determining the approximate number of products that will be returned. Thus, creating complexities not only with customers but with suppliers and reverse logistics' operations as well. This problem makes decision-making a complex process that needs integration of the method that allows the optimal collection practice for used components, a demand-matching oriented. This method, which is a type of Multiple Criteria Decision Making (MCDM), is the (AHP) Analytic Hierarchy Process and (AHP-EW) Entropy Weight method (Wang et al., 2019). Because of the challenges that reverse logistics imposes due to its complex operations and the scarcity of resources, some firms prefer outsourcing reverse logistics practices to the third-party reverse logistics provider (3PRLP). The most difficult part is choosing the optimal partner. The 3PRLP choosing is commonly documented as a hybrid-information multi-criteria decision making (HI-MCDM) problem integrating multiple factors which are typically in conflict with additional factors and articulated by numerous layouts of information ( $\mathrm{Li}$ et al., 2018). Table 4 summarizes the most effective solutions implemented in Europe.

Table 4. Reverse logistics' solution implemented in Europe (source: composed by authors)

\begin{tabular}{|l|l|l|l|}
\hline \multicolumn{1}{|c|}{ Method } & \multicolumn{1}{|c|}{ Description } & \multicolumn{1}{|c|}{ Author } & Country \\
\hline $\begin{array}{l}\text { The carbon-constrained } \\
\text { stochastic optimization } \\
\text { model }\end{array}$ & $\begin{array}{l}\text { Process for effectively managing the material, information, and cash flow } \\
\text { in order to regenerate value from EOU and EOL products through repair, } \\
\text { reuse, remanufacturing, recycling and reintroduction to the market, besides, } \\
\text { it also involves the proper treatment of the non-reusable and non-recyclable } \\
\text { parts. The reverse logistics network is comprised of the local collection } \\
\text { centers for EOU and EOL products, central collection center, remanufac- } \\
\text { turing and recycling center, energy recovery plant, waste treatment facility } \\
\text { and the market. First, the EOU and EOL products are collected at the local } \\
\text { collection centers which are located close to the customers, and this first- } \\
\text { level collection could be either a spontaneous customer return of EOU } \\
\text { and/or EOL products at the fixed depots or an organized return service per- } \\
\text { formed by the local waste management companies. Then, the locally col- } \\
\text { lected EOU and EOL products are sent to the central collection centers } \\
\text { where they will be inspected and disassembled for further distribution. The } \\
\text { disassembled parts will be sent for either remanufacturing/recycling or for } \\
\text { energy recovery through incineration/biochemical treatment, and the non- } \\
\text { reusable and non-recyclable parts will be sent for disposal at a landfill. }\end{array}$ & & Turkey \\
& & \\
& & \\
\end{tabular}


End of Table 4

\begin{tabular}{|c|c|c|c|}
\hline Method & Description & Author & Country \\
\hline $\begin{array}{l}\text { Application of social } \\
\text { commerce platform and }\end{array}$ & $\begin{array}{l}\text { The social commerce platform, a new business model of e-commerce, } \\
\text { makes use of Web } 2.0 \text { technologies and social media to support social-re- } \\
\text { lated exchange activities. It offers a platform connecting consumers and } \\
\text { companies integrating e-business, customer relationship management, tech- } \\
\text { nology support, and information systems. }\end{array}$ & $\begin{array}{l}\text { Han and } \\
\text { Trimi, } \\
2018\end{array}$ & Spain \\
\hline \multirow{4}{*}{$\begin{array}{l}\text { Application of Fuzzy } \\
\text { TOPSYS for choosing } \\
\text { 3PRLPs }\end{array}$} & $\begin{array}{l}\text { Selection of third-party reverse logistics providers (3PRLPs), which is } \\
\text { done by application of Fuzzy TOPSYS in } 3 \text { main streams. }\end{array}$ & & \multirow[t]{4}{*}{ Spain } \\
\hline & $\begin{array}{l}\text { Stream 1: Selection of the best third-party reverse logistics providers } \\
\text { (3PRLPs) or green suppliers. developed Interpretive Structural Modeling } \\
\text { (ISM) and fuzzy TOPSIS to guide the selection process, also used for cor- } \\
\text { rect evaluation and ranking of the decision criteria/priorities in selecting } \\
\text { the best 3PRLPs when a company decides to outsource reverse logistics ac- } \\
\text { tivities }\end{array}$ & $\begin{array}{l}\text { Han and } \\
\text { Trimi, } \\
2018\end{array}$ & \\
\hline & $\begin{array}{l}\text { Stream 2: Location decision problem to find the best place to locate a re- } \\
\text { manufacturing facility in a discrete space }\end{array}$ & & \\
\hline & $\begin{array}{l}\text { Stream 3: Reverse logistics process through the sorting process of reverse } \\
\text { logistics in the downstream photovoltaic industry }\end{array}$ & & \\
\hline $\begin{array}{l}\text { The triple bottom line } \\
\text { (TBL) approach }\end{array}$ & $\begin{array}{l}\text { Products are collected from the central point of the city. Inner city routing } \\
\text { is out of the scope of this study. } \\
\text { Cost of recycling does not change with years. } \\
\text { The numbers of collection sites are known and locations of the recycling } \\
\text { facilities are predetermined. }\end{array}$ & $\begin{array}{l}\text { Bal and } \\
\text { Satoglu, } \\
2018\end{array}$ & Turkey \\
\hline & The specific facility that can recover a product type is predetermined. & & \\
\hline & $\begin{array}{l}\text { Cost parameters are foreknown as material, operation, recycling, transpor- } \\
\text { tation, hiring, laying off and fixed cost. }\end{array}$ & & \\
\hline & The holding cost, stockout cost, and storage cost are disregarded & & \\
\hline $\begin{array}{l}\text { Performance measure- } \\
\text { ment (PM) system }\end{array}$ & $\begin{array}{l}\text { The PM is useful in benchmarking or setting standards for comparison with } \\
\text { best practices in other enterprises. The PM system model of RL developed } \\
\text { here is applied in the following steps: (1) presentation of the areas of suc- } \\
\text { cess; i.e., performance attributes, their criteria and performance measures, } \\
\text { which are used to measure the performance level as described by Shaik and } \\
\text { Abdul-Kader (2014); (2) calculation of the relative weights of the inner de- } \\
\text { pendent and interdependent relationships of criteria and attributes of suc- } \\
\text { cess by using the hybrid model (DEMATEL and fuzzy ANP and AHP } \\
\text { methods); and (3) rating the RL performance in each performance measure } \\
\text { and computing the overall performance score of the enterprise. }\end{array}$ & $\begin{array}{l}\text { Shaik and } \\
\text { Abdul- } \\
\text { Kader, } \\
2018\end{array}$ & $\begin{array}{l}\text { Switzer- } \\
\text { land }\end{array}$ \\
\hline
\end{tabular}

It is worth mentioning that in spite of the scarcity in the number of studies done in the reverse logistics' field in Asia, those studies mentioned above were able to change the concept of increasing efficiency of reverse logistic's performance in that region. Moreover, they have built the basis of the main starting points to explore more and more to increase RL performance.

\section{Overview of differences in reverse logistics in Europe and Asia}

The head-to-head comparison for increasing efficiency of reverse logistics' solutions implemented in Asia and Europe meet at a similarity of one important point, which is the inclusion of the multi-criteria decision-making model in every single final solution implemented. However, what differs is the type, objective, way, and utilization of resources to reach and apply such decisions. For instance, in Europe, the preservation of resources proved to be very important and is always considered manifested in the conservation of both energy and time. Moreover, environmental concerns such as eco-green strategies and decreasing pollution is an essential part, especially in reverse transportations and deliveries. Whereas, the Asian way of thinking didn't take these factors into consideration a lot replacing it by the speed and ease of the process of reverse logistics to maintain customer satisfaction and thus loyalty in order not to cause the loss of these customers. This doesn't mean that in Asia reducing waste of resources is not important, yet knowledge awareness and ways in which reverse logistics implemented could be enhanced more to preserve such resources. 


\section{Conclusions}

Almost every firm nowadays is implementing e-logistics in its daily operation. However, reverse e-logistics, a very crucial aspect, is often overlooked. Firms that neglected it, suffered a lot of costs and eventually had to terminate their operations. Fortunately, the solutions discussed in this research can increase the efficiency of reverse logistics when implemented effectively, yet developing countries in the middle east still didn't have such opportunities to conduct and test these researches. However, the reverse logistics system presents some limitations and need to be more developed. Firstly, a more comparative study is required in order to find new solutions techniques that can improve this system and find optimal solutions to increase its efficiency. Secondly, the interaction between experts was not addressed in this study and it would be important to tackle this point in further studies to evaluate reverse logistics performance according to other assessment's technical criteria. Additionally, some issues that extend beyond the core of supply chain management must be integrated by sustainability. These issues concern product design, manufacturing by items, the use of products manufactured during the manufacturing process, the extension of product life, the end of product's cycles and the recovery processes at the end of the stage. The future recommendation would be conducting more studies concerning reverse logistics in the Middle East region since there exists a great opportunity to seize there. The combination of the suggested recommendations with sustainability can help the firms to establish procedures in order to develop opportunities that can be seized in this area.

\section{Disclosure statement}

We declare that we do not have any competing financial, professional, or personal interests from other parties.

\section{References}

Agarwal, V., Govindan, K., Darbari, J. D., \& Jha, P. C. (2016). An optimization model for sustainable solutions towards implementation of reverse logistics under the collaborative framework. International Journal of Systems Assurance Engineering and Management, 7(4), 480-487. Retrieved from https://doi.org/10.1007/s13198-016-0486-3

Ang, A., \& Tan, A. (2018). Designing a reverse logistics network in an omnichannel environment in Asia. Log forum, 14(4), 519533. Retrieved from http://www.logforum.net

Bal, A., \& Satoglu, S. I. (2018). A goal programming model for sustainable reverse logistics operations planning and an application. Journal of Cleaner Production, 201, 1081-1091. https://doi.org/10.1016/j.jclepro.2018.08.104

Batarfi, R., \& Jaber, M. Y., \& Aljazzar, S. M. (2017). Profit maximization for a reverse logistics dual-channel supply chain with a return policy. Computers and Industrial Engineering, 106, 58-82. https://doi.org/10.1016/j.cie.2017.01.024

Bogataj, M., \& Grubbström, R. W. (2013). Transportation delays in reverse logistics. International Journal of Production Economics, 143(2), 395-402. https://doi.org/10.1016/j.ijpe.2011.12.007

Bouzon, M., Spricigo, R., Rodriguez, C. M. T., De Queiroz, A. A., \& Cauchick, Miguel P. A. (2015). Reverse logistics drivers: Empirical evidence from a case study in an emerging economy. Production Planning and Control, 26(16), 1368-1385. https://doi.org/10.1080/09537287.2015.1049239

Brüning Larsen, S., Masi, D., \& Cordes Feibert, D. (2017). How the reverse supply chain impacts the firm's financial performance A manufacturer's perspective. International Journal of Physical Distribution \& Logistics Management, 48(3), $284-307$. https://doi.org/10.1108/IJPDLM-01-2017-0031

Chileshe, N., Rameezdeen, R., Hosseini, M. R., Martek, I., Li, H. X., \& Panjehbashi-Aghdam, P. (2018). Factors driving the implementation of reverse logistics: A quantified model for the construction industry. Waste Management, 79, 48-57. https://doi.org/10.1016/j.wasman.2018.07.013

Chinda, T. (2017). Examination of factors influencing the successful implementation of reverse logistics in the construction industry: pilot study. Procedia Engineering, 182, 99-105. https://doi.org/10.1016/j.proeng.2017.03.128

Eskandarpour, M., Masehian, E., Soltani, R., \& Khosrojerdi, A. (2014). A reverse logistics network for recovery systems and a robust metaheuristic solution approach. International Journal of Advanced Manufacturing Technology, 74(9-12), 1393-1406. https://doi.org/10.1007/s00170-014-6045-7

Euchi, J., Bouzidi, D., \& Bouzid, Z. (2018). Structural analysis of acute success factors of the performance of reverse logistics relative to customer satisfaction. International Journal of Combinatorial Optimization Problems and Informatics, 10(2), 3956. Retrieved from https://ijcopi.org/index.php/ojs/article/view/102/105

Govindan, K., \& Bouzon, M. (2018). From a literature review to a multi-perspective framework for reverse logistics barriers and drivers. Journal of Cleaner Production, 187, 318-337. https://doi.org/10.1016/j.jclepro.2018.03.040

Han, H., \& Trimi, S. (2018). A fuzzy TOPSIS method for performance evaluation of reverse logistics in social commerce platforms. Expert Systems with Applications, 103, 133-145. https://doi.org/10.1016/j.eswa.2018.03.003

Lau, K. H., \& Wang, Y. (2009). Reverse logistics in the electronic industry of China: A case study. Supply Chain Management, 14(6), 447-465. https://doi.org/10.1108/13598540910995228

Li, Y. L., Ying, C. S., Chin, K. S., Yang, H. T., \& Xu, J. (2018). Third-party reverse logistics provider selection approach based on hybrid-information MCDM and cumulative prospect theory. Journal of Cleaner Production, 195, 573-584. https://doi.org/10.1016/j.jclepro.2018.05.213 
Lian, Z. (2017). Research on development strategy of automobile reverse logistics based on SWOT analysis. Procedia Engineering, 174, 324-330. https://doi.org/10.1016/j.proeng.2017.01.147

Linton, J. D., Klassen, R. D., \& Jayaraman, V. (2007). Sustainable supply chains: an introduction. Journal of Operations Management, 25(6), 1075-1082. https://doi.org/10.1016/j.jom.2007.01.012

Meixell, M., \& Luoma, P. (2015). Stakeholder pressure in sustainable supply chain management: A systematic review. Management, 48(3), 284-307. https://doi.org/10.1108/IJPDLM-05-2013-0155

Panigrahi, S. K., Kar, F. W., Fen, T. A., Hoe, L. K., \& Wong, M. (2018). A strategic initiative for successful reverse logistics management in retail industry. Global Business Review, 19(3), 151-175. https://doi.org/10.1177/0972150918758096

Prakash, C., \& Barua, M. K. (2015). Integration of AHP-TOPSIS method for prioritizing the solutions of reverse logistics adoption to overcome its barriers under fuzzy environment. Journal of Manufacturing Systems, 37, 599-615. https://doi.org/10.1016/j.jmsy.2015.03.001

Shaik, M. N., \& Abdul-Kader, W. (2013). Transportation in reverse logistics enterprise: A comprehensive performance measurement methodology. Production Planning and Control, 24(6), 495-510. https://doi.org/10.1080/09537287.2011.634180

Shaik, M. N., \& Abdul-Kader, W. (2018). A hybrid multiple criteria decision-making approach for measuring the comprehensive performance of reverse logistics enterprises. Computers and Industrial Engineering, 123, 9-25. https://doi.org/10.1016/j.cie.2018.06.007

Sirisawat, P., \& Kiatcharoenpol, T. (2018). Fuzzy AHP-TOPSIS approaches to prioritizing solutions for reverse logistics barriers. Computers and Industrial Engineering, 117, 303-318. https://doi.org/10.1016/j.cie.2018.01.015

Sun, Q. (2017). Research on the influencing factors of reverse logistics carbon footprint under sustainable development. Environmental Science and Pollution Research, 24(29), 22790-22798. https://doi.org/10.1007/s11356-016-8140-9

Tavengerwei, R. (2018). Using trade facilitation to assist MSMEs in E-commerce in developing countries. Journal of International Economic Law, 21(2), 349-378. https://doi.org/10.1093/jiel/jgy022

Tosarkani, B. M., \& Amin, S. H. (2018). A multi-objective model to configure an electronic reverse logistics network and third party selection. Journal of Cleaner Production, 198, 662-682. https://doi.org/10.1016/j.jclepro.2018.07.056

Tseng, S. C., \& Hung, S. W. (2014). A strategic decision-making model considering the social costs of carbon dioxide emissions for sustainable supply chain management. Journal of Environmental Management, 133, 315-322. https://doi.org/10.1016/j.jenvman.2013.11.023

Wang, F., Yu, Y., Wang, X., Ren, H., Shafie-Khah, M., \& Catalão, J. P. S. (2018). Residential electricity consumption level impact factor analysis based on wrapper feature selection and multinomial logistic regression. Energies, 11(5), 1-26. https://doi.org/10.3390/en11051180

Wang, H., Jiang, Z., Zhang, H., Wang, Y., Yang, Y., \& Li, Y. (2019). An integrated MCDM approach considering demandsmatching for reverse logistics. Journal of Cleaner Production, 208, 199-210. https://doi.org/10.1016/j.jclepro.2018.10.131

Waqas, M., Dong, Q. L., Ahmad, N., Zhu, Y., \& Nadeem, M. (2018). Critical barriers to implementation of reverse logistics in the manufacturing industry: A case study of a developing country. Sustainability (Switzerland), 10(11), 1-25. https://doi.org/10.3390/su10114202

Yu, H., \& Solvang, W. D. (2016). A stochastic programming approach with improved multi-criteria scenario-based solution method for sustainable reverse logistics design of waste electrical and electronic equipment (WEEE). Sustainability, 8(12), 1-28. https://doi.org/10.3390/su8121331

Yu, H., \& Solvang, W. D. (2017). A carbon-constrained stochastic optimization model with augmented multi-criteria scenariobased risk-averse solution for reverse logistics network design under uncertainty. Journal of Cleaner Production, 164, 12481267. https://doi.org/10.1016/j.jclepro.2017.07.066 